\title{
IMPLEMENTASI KEBIJAKAN PERATURAN DAERAH (PERDA) KABUPATEN SITUBONDO NO 13 TAHUN 2014 TENTANG PENATAAN DAN PEMBINAAN PASAR TRADISIONAL, PUSAT PERBELANJAAN DAN TOKO MODERN
}

\author{
Hasan Muchtar Fauzi \\ Hasanmuchtar.fauzi77@yahoo.com \\ Universitas Abdurachman Saleh Situbondo
}

\begin{abstract}
Abstrak
Penelitian ini membahas tentang implementasi kebijakan (PERDA) Kabupaten Situbondo no 13 tahun 2014 tentang penataan dan pembinaan pasar tradisional, pusat perbelanjaan dan toko modern. Perkembangan pasar modern menimbulkan permasalahan jika tidak mengikuti aturan tentang penataan dan pembinaan pasar tradisional, pusat perbelanjaan dan toko modern. Penelitian ini merupakan penelitian kualitatif dengan wawancara mendalam, observasi langsung, dan studi kepustakaan. Faktor yang mempengaruhi implementasi peraturan daerah kabupaten Situbondo nomor 13 tahun 2014 tentang penataan, pembinaan pasar tradisional, pusat perbelanjaan dan toko modern serta menghambat tercapainya tujuan kebijakan tersebut diantaranya minimnya sumberdaya finansial, minimnya keterpautan dan dukungan antar instansi dan pelaku usaha, inkonsistensi aturan, kurangnya komitmen pemerintah untuk melindungi hak-hak asasi masyarakat, dan minimnya akses masyarakat dalam partisipasi.
\end{abstract}

Kata Kunci: Peraturan Daerah, Pasar Tradisional, Pasar Modern

\section{PENDAHULUAN}

Di era globalisasi saat ini semakin banyak pengetahuan yang sangat berkembang begitu pesat, dengan begitu pemerintah dituntut harus semakin cepat dalam mengambil suatu kebijakan dalam menangani permasalahan dalam masyarakat, karena yang kita ketahui bahwa di kalangan masyarakat saat ini banyak sekali gejala sosial yang terjadi. Diantaranya adalah kebijakan pengembangan perekonomian di Indonesia bisa ditandai oleh maraknya pembangunan pusat perdagangan. Bentuk fisik pusat perdagangan bisa dibagi menjadi dua, yaitu pasar tradisional dan pusat perbelanjaan swalayan modern. Banyaknya pusat perbelanjaan modern yang memiliki persamaan fungsi dengan pasar tradisional maka menimbulkan persaingan antara keduanya.

Perbedaan yang mencolok antara pasar tradisional dengan pasar modern adalah dari sarana-prasarananya dan akhirnya berujung pada tingkat pelayanan. Keterbatasan sarana prasarana yang ada di pasar tradisional berdampak pula pada 
tingkat kepuasan konsumen menjadi rendah. Bagi konsumen tentu akan memilih alternatif lain yang lebih memuaskan dalam kenyamanan berbelanja seperti pasar modern. Pesatnya pertumbuhan pasar moderen membuat kota-kota besar dan sedang di Indonesia makin bersinar gemerlap. Akan tetapi kompetisi yang tidak berimbang serta kesuksesan ekspansi pasar modern di berbagai tempat, tidak menutup kemungkinan jumlah pasar tradisional yang gulung tikar akan terus bertambah. Keberadaan pasar moderen terancam karena semakin menjamurnya swalayan dengan sistem waralabanya yang mampu mempenetrasi konsumen kepelosok Desa. (Suryadarma at all;2007)

Dari data statistik yang dipublikasikan Asosiasi Pedagang Pasar Seluruh Indonesia (APPSI) mengungkapkan keluhan dari para pedagang bahwa, sepanjang tahun 2005 omset penjualan para pedagang pasar tradisional turun $30 \%$ persen sampai $40 \%$ persen akibat terlalu ekspansifinya pengembangan pasar moderen terutama hiper market, mini market seperti Indomart dan Alramart. Sudah banyak Kios pasar tradisional yang harus tutup, karena sulit bersaing dengan pasar modern. Data dari Asosiasi Pedagang Pasar Seluruh Indonesia (APPSI), menegaskan bahwa pada tahun 2005 seperti dikutip website Kementerian Koperasi dan UKM menyebutkan bahwa, sekitar 400 toko di pasar tradisional tutup usaha setiap tahunnya. (Indrakh, 2007:3). Riset AC Nielsen pada tahun 2006 menunjukkan bahwa pangsa pasar modern meningkat $11.8 \%$ selama lima tahun terakhir. Jika pangsa pasar dari pasar modern pada tahun 2001 adalah $24.8 \%$ maka pangsa pasar tersebut menjadi $32.4 \%$ tahun 2005. Hal ini berarti bahwa dalam periode 2001/2006, sebanyak $11.8 \%$ konsumen ritel Indonesia telah meninggalkan pasar tradisional dan beralih ke pasar modern.Napitupulu (dalam Pilyang, 2010:20).

Untuk menghindari semakin tersisihnya pasar tradisional dalam era persaingan perdagangan bebas saat ini, (1) pemerintah harus segera melakukan langkah-langkah strategis untuk melindungi pasar tradisional bisa dilakukan pemerintah dengan pemberdayaan pasar tradisional melalui pembangunan fasilitas dan renovasi fisik pasar, peningkatan kompetensi perdagangan dan pengelola pasar, melaksanakan program pendampingan pasar, penataan dan pembinaan 
pasar, mengevaluasi pengelolaan pasar tradisional, (2) memperketat proses perizinan dalam pendirian ritel baru. Pemerintah harus lebih selektif dan ketat dalam proses perizinan yang dilakukan ritel-ritel baru, terutama ritel asing. (3) meregulasi penataan dan kebijakan zonasi ritel asing dengan pasar tradisional. Misalnya, zonasi kawasan, zonasi jarak, dan zonasi rasio penduduk. (4), mendorong pengelolaan pasar tradisional ke arah pola pasar modern. Terlepas dari berbagai solusi tersebut, hal utama yang paling dibutuhkan adalah niat dan langkah serius pemerintah untuk benar-benar bisa melindungi pasar tradisional dari serbuan ritel asing. (http://ekonomi.kompas.com).

Perkembangan otonomi daerah telah membawa sejumlah implikasi terhadap perubahan fungsi-fungsi pemerintah dalam berbagai kebijakan, baik dalam kelembagaan, pemanfaatan dan penggalian sumber daya alam, sumber daya manusia serta sumber-sumber kegiatan ekonomi di berbagai bidang. Pemerintah daerah harus dapat menggali seluruh potensi yang ada di dalam pengelolaan keuangan melalui peningkatan Pendapatan Asli Daerah (PAD) dan sumbersumber keuangan lainnya untuk menunjang pelaksanaan pembangunan sehingga diharapkan daerah dapat berkembang secara mandiri.

Kebijakan yang dilakukan Pemerintah Daerah (Pemda) Kabupaten Situbondo untuk meningkatkan kontribusi sektor perdagangan dan jasa adalah melalui peningkatan dan perbaikan sarana dan prasarana perekonomian yang ada.Salah satu strategi yang dilaksanakan oleh PEMDA yaitu dengan meningkatkan aktivitas pasar-pasar tradisional sebagai basis kekuatan ekonomi rakyat.Pengembangan pasar-pasar tradisional diarahkan pada penyediaan lahan, pembangunan dan pemanfaatan pasar di setiap kecamatan sebagai sentra ekonomi.

Akan tetapi banyaknya minimarket waralaba modern yang bermunculan di berbagai kecamatan dan kota menjadi persoalan tersendiri bagi pedagang pasar tradisional. Berdasarkan hasil observasi awal 2018 di beberapa pasar tradisional di wilayah Kabupaten Situbondo, rata-rata pasar tradisional yang ada selalu berdampingan dengan adanya minimarket waralaba modern. Kemunculan minimarket waralaba modern seperti Indomart dan Alfamart di lingkungan masyarakat nampaknya dianggap telah memberikan dampak negatif terhadap laju 
pertumbuhan pasar tradisional. Oleh sebab ituBupati Situbondo melalui kebijakan Peraturan Daerah (PERDA) Kabupaten Situbondo No 13 Tahun 2014 Tentang Penataan Dan Pembinaan Pasar Tradisional, Pusat Perbelanjaan Dan Toko Modern masih belum berjalan dengan maksimal penerapannya.

Berdasarkan fakta yang diuraikan di atas, maka untuk itu perlu diketahui:

1. Bagaimana implementasi kebijakan Pemerintah Daerah dalam menata dan membina pasar tradisional, pusat perbelanjaan dan toko modern di Kabupaten Situbondo?.

2. Faktor apa saja yang mempengaruhi implementasi Peraturan Daerah No.13 tahun 2014 tentang penataan dan pembinaan pasar tradisional, pusat perbelanjaan dan toko modern?.

\section{METODE PENELITIAN}

Jenis data yang dikumpulkan dalam penelitian ini adalah data primer dan data sekunder. Data primer diperoleh dari hasil wawancara langsung dengan para pengambil kebijakan yang berasal dari Lembaga/Instansi Pemerintah, Tokoh Masyarakat, Swasta dan para pedagang. Data primer mencakup:

(1) Proses perencanaan kebijakan pengembangan pasar

(2) Penerapan program dan dampaknya.

Data sekunder diperoleh dari studi pustaka dan data penunjang yang relevan dengan penelitian. Data sekunder diperoleh dari Dinas Perindustrian, Perdagangan dan Koperasi (Disperindagkop) Kabupaten Siubondo, Badan Perencanaan Pembangunan Daerah (Bapeda), Dinas Pendapatan Daerah (Dispenda), Dinas Tata Kota dan Pertamanan (DTKP), Dinas Lingkungan Hidup dan Kebersihan (DLHK), Badan Pusat Statistik (BPS), Unit Pelaksana Teknis Dinas Pasar Tradisional (UPTD). Data penunjang diperoleh dari laporan hasil penelitian terkait, jurnal, internet serta sumber-sumber lainnya.

Data yang dikumpulkan;

a. Tingkat kepentingan dan pengaruh stakeholders terhadap keberhasilan program.

b. Rencana strategis, rencana pembangunan jangka menengah daerah, rencana 
tata ruang wilayah, dan lain sebagainya.

c. Persepsi masyarakat tentang pengembangan pasar tradisional dan penataan toko modern terdiri dari tujuan, aspek, kreteria dan alternatif strategi kebijakan

\section{HASIL PENELITIAN DAN PEMBAHASAN}

Implementasi Peraturan Daerah Kabupaten Situbondo No 13 Tahun 2014 Tentang Penataan, Pembinaan Pasar Tradisional, Pusat Perbelanjaan Dan Toko Modern.

1. Asas Kemanusian

Pemerintah kabupaten Situbondo telah mengupayakan perlindungan terhadap hak-hak para pedagang terutama pedagang kecil dengan mengatur harga kepada pelaku usaha modern untuk melindungi kegiatan usaha perdagangan yang dijalankan oleh masyarakat kecil dan juga upaya pengaturan jarak pendirian atau zonasi antara minimarket terhadap pasar tradisonal maupun pelaku usaha kecil sejenis. Namun pada kenyataannya masih banyak minimarket yang lokasi pendiriannya tidak sesuai dengan ketentuan peraturan yang berlaku, dan cenderung menimbulkan kecemburuan sosial karena berpengaruh terhadap pendapatan pelaku usaha kecil maupun pedagang pasar tradisional.sehingga faktanya perlindungan terhadap padagang kecil dan pedagang pasar tradisonal dari sisi asas kemanusiaan dalam penataan dan pembinaan pusat perbelanjaan dan toko modern belum berjalan secar maksimal penerapannya.

\section{Asas Keadilan}

Berdasarkan peraturan daerah kabupaten Situbondo nomor 13 tahun 2014 yang dimaksud prinsip keadilan adalah pengaturan dalam penataan dan pembinaan pasar tradisional, pusat perbelanjaan dan toko modern mencerminkan keadilan secara proporsional bagi setiap warga masyarakat. Pemenuhan hak prinsip keadilan ini ditekankan penyerapan tenaga kerja oleh pelaku usaha wajib memperhatikan penduduk lokal sekitar tempat berdirinya toko modern.dengan memperhatikan penduduk lokal sebelum menggunakan tenaga kerja dari wilayah lain kecuali untuk posisi yang membutuhkan spesifikasi atau keahlian khusus dalam mengelola pasar modern. Hal tersebut agar dimaksudkan rasa keadilan 
dirasakan masyarakat sekitar dan tidak terjadi ketimpangan sosial yang sangat berarti. Mitra yang baik dengan memberikan ruang terhadap UKM melalui kerjasama dibidang persewaan tempat, dan persaingan harga yang sehat tentu tidak akan menimbulkan kecemburuan sosial bagi masyarakat kecil.

\section{Asas Kesamaan Kedudukan}

Peraturan daerah kabupaten Situbondo nomor 13 tahun 2014 menjelaskan asas kesamaan kedudukan adalah bahwa kedudukan hukum para stakeholder dalam sektor perdagangan sama dan seimbang. Pemenuhan asas kesamaan kedudukan dalam implementasi peraturan daerah nomor 13 tahun 2014 berkaitan dengan proses memperoleh rekomendasi sebelum mendapatkan perizinan diberlakukan sama kepada semua pelaku usaha yang sesuai dengan jenis usahanya. Ketentuan yang terkandung dalam PERDA tersebut juga diberlakukan kepada toko modern yang sudah berdiri sebelum PERDA nomor 13 tahun 2014 di undangkan.

Melalui ketentuan peralihan yang terdapat dalam PERDA nomor 13 tahun 2014 bahwa perusahaan atau ritel yang sudah berdiri sebelum PERDA nomor 13 tahun 2014 dijelaskan bahwa perusahaan yang sudah berdiri sebelum di undangkan perda tersebut diberi waktu sampai dengan masa ijinnya telah habis. Hal ini untuk mewujudakankan kesamaan semua toko modern dalam menaati semua ketentuan yang terdapat dalam peraturan daerah kabupaten Situbondo nomor 13 tahun 2014 tentang penataan, pembinaan pasar tradisional, pusat perbelanjaan dan toko modern.

\section{Asas Kemitraan}

Pemenuhan asas kemitraan dalam implementasi PERDA nomor 13 tahun 2014 sudah berjalan dengan adanya pemberian lahan bagi pelaku usaha mikro yang disediakan oleh pusat perbelanjaan maupun toko modern. selain itu pemasaran produk UMKM juga tela dilakukan oleh beberapa swalayan maupun minimarket. Kegiatan kemitraan lainnya yaitu pembinaan yang dilakukan oleh beberapa minimarket terhadap pelaku UMKM.Hal ini bertujuan agar pelaku uasaha toko modern dapat tetap memberdayakan UMKM disekitarnya. 
Kemitraan yang luas adalah kemitraan yang terjalin antara tiga elemen, yaitu pemerintah, pengusaha dan masyarakat. Ketiga komponen tersebut harus saling berpegang teguh tujuan kemitraan dan tujuan implementasi PERDA nomor 13 tahun 2014 dapat terlaksana dengan baik.

\section{Asas Ketertiban Dan Kepastian Hukum}

Kegiatan yang dilakuakn oleh seluruh masyarakat kabupaten situbondo harus menimbulkan ketertiban, dalam kata lain keberadaan usahanya harus mempunyai izin dan sesuai dengan ketentuan yang di atur dalam perda nomor 13 tahun 2014. Kegiatan usaha terutama yang dilajalakan oleh pelaku usaha pusat perbelanjaan maupun toko modern harus menaati ketentuan yang terdapat dalam PERDA nomor 13 tahun 2014 agar keberadaannya sesuai dan tidak menimbulkan gangguan ketertiban dimasyarakat. Kegiatan yang suai dengan peraturan tersebut dimaksudkan untuk melindungi hah-hak para pelaku usaha kecil maupun pasar tradisional.diman dalam beberapa ketentuan diatur menegnai izin yang harus dimiliki oleh pelaku usaha dalam mendirikan bangunan maupun izin melakukan kegiatan usaha.

Masih minimnya koordinasi para pelaku usaha modern dengan dinas terkait terutama dinas yang mengatur segala ketentuannya yang mengakibatkan adanya beberapa minimarket yang berdiri tidak sesuai dengan ketentuan yang diatur dalam PERDA nomor 13 tahun 2014, faktor lokasi strategis dengan para pelanggan atau konsumen dan langsung mengadakan perjanjian kontrak dengan pemilik tanah sering menjadi penyebab diabaikannya kordinasi dengan Disperindag untuk mendapatkan rekomendasi perizinan dan juga melakukan perzinan dengan BPPT. Oleh sebab itu pemerintah harus menindak tegas para pelaku pasar atau pengusaha yang sembarangan membangun minimarket yang tidak berijin dengan menutup bisnis tersebut.

\section{Asas Kelestarian Lingkungan}

Kegiatan yang dilakukan oleh pelaku usaha pusat perbelanjaan, toko modern maupun pasar tradisional harus memperhatikan kelestarian lingkungan disekitarnya. Daya tampung dan daya dukung lingkungan harus dipenuhi oleh setiap pelaku usaha dan pasar tradisional. Pemenuhan fasilitas dan yang 
menunjang daya tampung maupun daya dukung lingkungan harus disediakan oleh pelaku usaha, penyediaan terbuka hijau, sarana parkir, maupun MCK serta pembuangan harus dimiliki oleh pelaku usaha maupun pasar tradisional.pemenuhan fasilitas penunjang yang mampu memberikan daya tampung dan daya dukung lingkungan juga dimaksudkan agar dapat memberikan kenyamanan kepada konsumen pada saat berbelanja.

Pemenuhan fasilitas dalam memenuhi daya dukung dan daya tampung lingkungan sudah ditunjukkan oleh pelaku usaha dengan tersedianya fasilitas seperti MCK (Mandi Cuci Kakus), tempat pembuangan MCK yang lebih baik, tempat sampah, lain halnya dengan pasar tradisional, dimana dari penataan dan pembinaan masih sering dijumpai lingkungan yang kotor dan becek terutama pada saat musim penghujan. Masih sering ditemukannya kondisi pasar tradisional yang kumuh dan becek membuktikan belum sempurnanya penataan dan pembinaan yang dilakukan dalam hal pemenuhan asas kelestarian lingkungan.

7. Asas Kejujuran Usaha

Sesuai peraturan daerah kabupaten situbondo nomor 13 tahun 2014 yang dimaksudakan asas kejujuran usaha adalah bahwa penyelenggraan pusat perbelanjaan dan toko modern mengutamakan kejujuran dalam usaha memperoleh keuntungan. Pemenuhan asas kejujuran usaha dalam implementasi PERDA tersebut sudah berjalan dengan baik.Pengusaha toko modern dalam hal pemenuhan barang-barang yang dijual sudah jelas mengenai asal-usul kualitasnya, sehingga masyarakat yang menjadi konsumen tidak ragu aka asal muasal barang yang dibelinya.

Pemerintah melalui dinas perindustrian dan perdagangan rutin melakukan operasi pasar untuk mengantisipasi adanya kecurangan yang dilakukan pelaku usaha baik pengusaha toko modern maupun pedagang yang ada dipasar tradisional. operasi ini mengantisipasi tidak adanya makanan yang tidak berizin BPOM, makanan kadaluarsa, serta makanan yang tidak layak dijual.

\section{Asas Persaingan Sehat}

Usaha yang dijalankan baik para pelaku usaha maupun pasar tradisional harus dilakukan secara jujur.Tertib hukum dan tidak menghambat persainngan 
usaha secara umum. Persaingan tidak sehat apabila dilakukan dengan kelas yang berbeda seperti supermarket dengan pasar tradisonal, maka perlu diperhatikanlah persaingan tersebut agar tetap dapat melindungi hak-hak pelaku usaha kecil dan pedagang pasar tradisonal.

Kondisi adanya beberapa minimarket maupun supermarket yang lokasi berdirinya dekat dengan dengan pasar tradisonal perlu dilakukan pembinaan terhadap para pedagang pasar tradisonal agar mereka dapat tetap melakukan usahanya tanpa khawatir kehilangan konsumen, pemerintah wajib melakukan pembinaan dan arahan terkait upaya untuk tetap dapat bertahan dalam persaingan yang terjadi. Disperindag melalui bidang pengelolaan pasar tradisonal dalam menanggapi banyaknya minimarket yang terlanjur dekat beroprasi dekat dengan pasar tradisonal melakukan berbagai upaya untuk tetap mengawal dan memberikan pembinaan maupun pengarahan kepada pedagang pasar tradisonal.

Akan tetapi banyak pula minimarket yang tempatnya berdekatan dengan pasar tradisonal dan toko tradisional menyebabkan kemunduran bahkan terancam gulang tikar. Seperti yang kita lihat bahwa toko-toko kecil sekarang sepi pembeli, karena tidak diminati oleh konsumen.Orang banyak yang memilih berbelanja diminimarket atau toko modern dengan alasan kenyamanan berbelanja. Ada diskon atau potongan harga, ada paket promo di hari-hari tertentu, bahkan harga produk lebih murah dari toko klontong dan pasar tradisional.

Faktor Yang Mempengaruhi Implementasi Peraturan Daerah Kebupaten Situbondo Nomor 13 Tahun 2014 Tentang Penataan Dan Pembinaan Pasar Tradisonal, Pusat Perbelanjaan Dan Toko Modern.

Faktor-faktor yang menjadi penghambat implementasi peraturan daerah kabupaten Situbondo nomor 13 tahun 2014 diantaranya: 1) sumberdaya finansial; 2) keterpautan dan dukungan antar berbagai institusi; 3) Inkonsistensi aturan; 4). Komitmen aparat terhadap tujuan kebijakan; dan 5) Akses kelompok-kelompok luar untuk berpartisipasi dalam implementasi kebijakan.

Faktor sumberdaya finansial atau anggaran merupakan hal yang tak dapat dipungkiri dalam mendukung pengimplmentasian suatu kebijakan. Setiap program tentu memerlukan pekerjaan-pekerjaan administrasi dan teknis, memonitor 
program, mengelola sumberdaya lain yang kesemua itu memerlukan anggaran yang mendukung terutama untuk mendukung implementasi peraturan daerah kabupaten Situbondo nomor 13 tahun 2014 tentang penataan dan pembinaan pasar tradisonal, pusat perbelanjaan dan toko modern.

Minimnya anggaran memaksa terhambatnya sosialisasi ataupun pembinaan kepada masyarakat maupun pembinaan dan penataan terhadap pedagang pasar tradisional dan sarana prasarana pasar tradisonal. Anggaran sangat diperlukan baik untuk melakukan sosialisasi dan pembinaan terhadap pelaku usaha kecil sejenis dan pedagang pasar tradisonal maupun untuk penataan dan perawatan fasilitas sarana prasarana pasar tradisonal agar dapat menunjang kenyamanan konsumen dalam berbelanja agar tetap dapat bersaing denga pusat perbelanjaan maupun toko modern.

Faktor keterpautan dan dukungan antara berbagai instustusi menjadikan suatu program akan sukses diimplementasikan jika terjadi koordinasi yang baik dilakukan antar berbagai instansi terkait. Baik secara vertical maupun horizontal. Tak terkecuali koordinasi yang dilakukan oleh instansi terkait yaitu Disperindag, BPPT, Satpol PP dan dinas yang mempunyai TUPOKSI terkait rekomendasi perizinan usaha di kabupaten Situbondo.

Akan tetapi berdasarkan hasil penelitian dilapangan, koordinasi masih belum terjalin dengan rapih antara instansi terkait. Minimnya koordinasi dengan pelaku usaha juga mengakibatkan minimya pemahaman pelaku usaha akan ketentuan-ketentuan yang terdapat dalam PERDA nomor 13 tahun 2014 sehingga pelaku usaha toko modern cenderung mengabaikan peran pemeintah dalam penataan dan pembinaan pusat perbelanjaan dan toko modern. koordinasi tidak hanya dilakukan antar instansi maupun dengan pelaku usaha tetapi juga masyarakat. Kurangnya koordinasi ini menyebabkan adanya kurangnya pemahaman dimasyarakat mengenai kebijakan-kebijakan maupun programprogram yang dikeluarkan oleh pemerintah.

Faktor inkonsistensi aturan dalam penataan dan pembinaan pasar tradisional, pusat perbelanjaan dan toko modern menyebabkan kegagalan pengimplementasiannya. Konsistensi aturan dalam hal ini perturan daerah 
diperlukan agar pelaku usaha memperoleh kejelasan dan keadilan mengenai ketentuan-ketentuan yang mengatur didalamnya. Perbedaan mengenai jarak yang diatur dalam setiap PERDA yang berlaku membuat minimarket-minimarket yang berdisi seusai dengan ketentuan lama mendapatkan dispensasi dengan adanya ketentuan peralihan. Dimana dalam ketentuan peralihan di atur bagi pusat pusat perbelanjaan modern yang telah meiliki izin usaha sebelum PERDA nomo 13 tahun 2014 diundangkan wajib menyesuaikan ketentuan mengenai sebagaiman yang dimaksu dalam pasal 26 toko modern yang telah berdiri dan berizin sebelum berlakunya peraturan daereah ini nyatakan tetap berlaku sebagaiman masa berlakunya habis.

Akan tetapi para pedagang tradisonal tidak tahu kapan izin yang berlaku bagi minimarket berakhir masanya. Sehingga ketidakjelasan peraturan tersebut akan dimanfaatkan oleh para pemilik modal yang mempunyai usaha toko modern. Sedangkan pasar tradisonal dipaksa bersaing dan menyesauaikan dengan keadaan tersebut dengan mini market yang lokasinya dekat dengan mereka.

Faktor yang menghambat lainnya adalah minimnya komitmen aparat terhadap tujuan kebijakan, kometmen mencakup keseriusan dan kesungguhan agar penerapan suatu perturan ataupun kebijakan bisa berjalan dengan baik dan diterima serta dipatuhi oleh sasaran dari kebiajakan tersebut. Pembiaran pemerintah terhadap minimarket yang melanggar merupakan bentuk komitmen yang belum dilaksanakan oleh Disperindag sebagai dinas teknis. Pembiaran tersebut justru cenderung tidak melindungi hak-hak masyarakat kecil dalam sektor perdagangan sehingga menuntut mereka barsaing dengan toko modern.

Faktor akses kelompok-kelompok luar untuk berpartisipasi dalam implementasi kebijakan juga menjadi faktor penghambat implmentasi PERDA nomor 13 tahun 2014. Sebauh program akan mendapatkan dukungan banyak ketika kelompok-kelompok luar, dalam artian diluar pihak pembuat kebijakan masyarakat ikut terlibat dalam kebijakan tersebut dan tidak hanya menjadikan mereka sebagai penonton tentang adanya suatu kebijakan ataupun program di wilayah mereka. Kesadaran masyarakat mengenai adanya kebijakan pemerintah yang ada disekitar wilayahnya masih terlihat rendah. Kaitannya dengan 
operasional toko-toko modern dilingkungannya, masyarakat masih acuh terutama dalam pembangunan awal.Ini menunjukkan bahwa masyarakat kita seringkali masih permisif terhadap masalah-masalah sosial yang merugikan mereka. Yang menyebabkan orang lain akan bertindak semena-mena terhadap masyarakat yang lemah dan tidak berdaya. Seharusnya yang mempunyai pengetahuan dan wawasan yang luas dapat menyadarkan masyarakat yang tertindas untuk proaktif terhadap kebijakan yang merugikan mereka.

\section{KESIMPULAN DAN SARAN \\ Kesimpulan}

Implementasi Peraturan Daerah Kabupaten Situbondo nomor 13 tahun 2014 tentang penataan, pembinaan pasar tradisional, pusat perbelanjaan dan toko modern belum berjalan baik, dibuktikan dengan masih belum terpenuhinya beberapa asas yang menjadi indikator kesuksesan kebijakan penataan dan pembinaan pasar tradisional, pusat perbelanjaan dan toko modern. Asas-asas yang belum terpenuhi diantaranya: asas kemanusiaan, asas ketertiban dan kepastian hukum, asas kelestarian lingkungan, dan asas persaingan sehat. Sedangkan asas yang sudah terpenuhi dalam implementasi peraturan daerah kabupaten Situbondo nomor 13 tahun 2014 diantaranya: asas keadilan, asas kesamaan kedudukan, asas kemitraan dan asas kejujuran usaha.

Faktor yang mempengaruhi implementasi peraturan daerah kabupaten Situbondo nomor 13 tahun 2014 tentang penataan, pembinaan pasar tradisional, pusat perbelanjaan dan toko modern serta menghambat tercapainya tujuan kebijakan tersebut diantaranya minimnya sumberdaya finansial, minimnya keterpautan dan dukungan antar instansi dan pelaku usaha, inkonsistensi aturan, kurangnya komitmen pemerintah untuk melindungi hak-hak asasi masyarakat, dan minimnya akses masyarakat dalam partisipasi.

\section{Saran}

Berdasarkan hasil penelitian yang sudah dilakukan, dengan memperhatikan pemenuhan asas-asas dalam implementasi peraturan daerah kabupaten Situbondo nomor 13 tahun 2014 tentang penataan, pembinaan pasar 
tradisional, pusat perbelanjaan dan toko modern, serta faktor-faktor yang mempengaruhinya, peneliti memberikan rekomendasi antar lain :

1. Implementasi Peraturan Daerah Kabupaten Situbondo Nomor 13 Tahun 2014

a) Mempertegas penegakan Peraturan Daerah Kabupaten Situbondo nomor 13 tahun 2014 tentang penataan, pembinaan pasar tradisional, pusat perbelanjaan dan toko modern agar tetap memperhatikan asas kemanusiaan masyarakat dalam sektor perdagangan .

b) Mempertegas penegakkan Peraturan Daerah Kabupaten Situbondo nomor 13 tahun 2014 tentang penataan, pembinaan pasar tradisional, pusat perbelanjaan dan toko modern agar tetap mewujudkan asas ketertiban dan kepastian hukum,

c) Menata dan membina pasar tradisional agar memenuhi asas kelestarian lingkungan dalam mewujudkan kenyamanan konsumen.

d) Mengatur dan menata pasar tradisional, pusat perbelanjaan dan toko modern dalam mewujudkan asas persaingan sehat.

2. Faktor Penghambat Peraturan Daerah Kabupaten Situbondo Nomor 13 Tahun 2014

a) Perlunya dukungan sumberdaya finansial baik untuk pembinaan pelaku usaha kecil dan pedagang pasar tradisional maupun untuk penataan dan perawatan sarana prasarana pasar tradisional.

b) Meningkatkan komitmen pemerintah dalam menegakkan Peraturan Daerah Kabupaten Situbondo nomor 13 tahun 2014 agar tetap melindungi hak-hak asasi masyarakat dalam sektor perdagangan.

c) Meningkatkan koordinasi antara 3 (tiga) elemen yakni pemerintah, pelaku usaha dan masyarakat

d) Mengkaji PERDA terutama pasal ketentuan peralihan yang mengatur ketentuan pemberian izin bagi minimarket yang berdiri tidak sesuai dengan ketentuan.

e) Meningkatkan partisipasi masyarakat dalam setiap kebijakan pemerintah. 


\section{DAFTAR PUSTAKA}

Abdrabo, Mohamed A. dan Mahmoud A. Hassaan.Stakeholder Analysis.www.wadi- unifi.com.[30 Agustus 2007].

Abdul wahab, Solichin.(2001). Analisis Kebijaksanaan dari formulasi ke implementasi kebijaksanaan negara. Jakarta. PT Bumi aksara.

Afifudin.(2012). Metodologi penelitian kualitatif.Bandung.Pustaka setia.

DFID.2006. Manajemen Daur Proyek dan Penggunaan Kerangka Kerja Logis.http://www.deliveri.org[30 Agustus 2007].

Dunn, William N. 2003. Pengantar Analisis Kebijakan Publik. Penerjemah: Samodra Wibawa. Gajah Mada University Press. Yogyakarta.

Dwijowijot, Riant Nugroho. 2003. Kebijakan Publik; Formulasi, Implementasidan Evaluasi.PT. Elex Media Komputindo. Jakarta.

Ismawan, B. 2003.Peran Lembaga Keuangan Mikro dalam Otonomi Daerah.Jurnal Ekonomi dan Bisnis. Fakultas Ekonomi. Universitas Gajah Mada.Yogyakarta.

Istiningtiyas, A. Diyah. Analisis Kebijakan Dan Strategi Pengembangan Pasar radisional Di Kota Bogor. Skripsi.Program Studi Ekonomi Pertanian Dan Sumberdaya. Fakultas Pertanian Institut Pertanian Bogor.

Kartini, Rini. 2002. Dampak Perpindahan Lokasi Pasar Induk terhadap Sistem Pemasaran Sayur Mayur di Kota Bogor.Skripsi.Program Sarjana. Jurusan Ilmu-ilmu Sosial Ekonomi Pertanian. Fakultas Pertanian. Institut Pertanian Bogor. Bogor.

Kencana, Inu. (2006). Ilmu Administrasi Publik. Jakarta. PT Rineka Cipta.

Kusumanegara, Solahuddin. (2010). Model dan Aktor Dalam Proses Kebijakan Publik.Yogyakarta.Gava Media Jogjakarta.

Lamadlauw, Meidina Trijadi. 2006. Strategi Pengembangan Usaha Kecil dan Menengah Agroindustri di Kabupaten Bogor.Tesis. Sekolah Pasca Sarjana. Institut Pertanian Bogor. Bogor.

Moeloeng, Lexy J. (2007).Metodologi Penelitian Kualitatif. Bandung. PT. Remaja Rosdakarya

Mishra, Satish C. 2005. Pembuatan Kebijakan Demokratis dalam Konteks yangBerubah.United Nations Support Facility for Indonesian Recovery. 
Jakarta.

Nugroho, Riant. (2006). Kebijakan Publik untuk Negara-Negara 16 Berkembang.Jakarta.PT. Elex Media Komputindo.

Rahayu, Sri. 2005. Analisis Penentuan Lokasi Optimal Pasar Tradisional sebagai Pusat Perdagangan di Kota Bekasi dalam Pengembangan Wilayah. Skripsi.Program Sarjana.Program Studi Ekonomi Pertanian dan Sumberdaya. Fakultas Pertanian. Institut Pertanian Bogor. Bogor.

Rangkuti, Khairunnisa. 2005. Analisis Pengembangan Pasar Tradisional dan Dampaknya Terhadap Pembangunan Wilayah (Studi Kasus Pasar Tradisional di Kota Medan). Tesis. Program Pasca Sarjana. Program Studi Perencanaan Pembangunan Wilayah dan Pedesaan. Universitas Sumatera Utara.

Saaty, Thomas L. 1993. Pengambilan Keputusan Bagi Para Pemimpin. Penerjemah: Liana Setiono. PT. Pustaka Binaman Pressindo. Jakarta.

Safitri, Benny. Analisis Respon Stakeholders terhadap Kebijakan Perluasan Kawasan di Taman Nasional Gunung Halimun - Salak (Studi Kasus Kabupaten Lebak, Provinsi Banten). Skripsi.Program Sarjana.Departemen Konservasi Sumberdaya Hutan dan Ekowisata. Fakultas Kehutanan. Institut Pertanian Bogor. Bogor.

Schmeer, Kammi. 2007. Stakeholder Analysis at a Glance. www.lachsr.org [7 Januari 2008].

Tandiyar, Alan. 2002. Kajian Perkembangan Pasar Tanah Baru Sebagai Acuan Bagi Pembangunan Pasar Tradisional Baru di Kota Bogor. Tesis.Magister Teknik Pembangunan Kota. Universitas Diponegoro. Semarang.

Untoro, Fathoni. 2006. Evaluasi Pelaksanaan Kesepakatan Konservasi Desa (KKD) dalamKerinci Seblat-Integrated Conservation and Development

.....2007.No.112. Penataan dan Pembinaan Pasar Tradisional Pusat Perbelanjaan dan Toko Modern.Jakarta: Peraturan Presiden Republik Indonesia.

2008.No.53/M-DAG/PER/12. Pedoman Penataan Dan Pembinaan Pasar Tradisional Pusat Perbelanjaan dan Toko Modern.Jakarta: Peraturan Menteri Perdagangan Republik Indonesia

......2014.No.13. Penataan dan Pembinaan Pasar Tradisional Pusat Perbelanjaan dan Toko Modern.Situbondo: Peraturan Pemerintah Daerah Kabupaten Situbondo. 